\title{
Menkes disease: what a multidisciplinary approach can do
}

This article was published in the following Dove Press journal:

Journal of Multidisciplinary Healthcare

17 August 2016

Number of times this article has been viewed

\author{
Rahul Ojha' \\ Asuri N Prasad ${ }^{1-4}$ \\ 'Department of Pediatrics, ${ }^{2}$ Section \\ of Pediatric Neurology, ${ }^{3}$ Division of \\ Clinical Neurological Sciences, ${ }^{4}$ Child \\ Health Research Institute, Schulich \\ School of Medicine and Dentistry, \\ University of Western Ontario, \\ London, ON, Canada
}

\begin{abstract}
Disorders of copper homeostasis are currently recognized across the life span. Their recognition and links to human disease have spanned several decades, beginning with the recognition of a degenerative disorder in the offspring of sheep grazing in copper-deficient pastures, through to the description of infants suffering from a progressive neurodegenerative disorder characterized by epileptic seizures, developmental regression, failure to thrive, and an unusual hair quality (giving the condition its distinctive label of "kinky hair disease"). In this review, we trace the historical background and describe the biochemistry and physiology of copper metabolism and transport, inheritance patterns, molecular genetics, and genotype-phenotype correlations based on current understanding of the disorder. It is clear from the clinical presentations and variants that disorders of copper homeostasis include phenotypes ranging from mild occipital horn syndrome to intermediate and severe forms of classical Menkes disease. The symptoms involve multiple organ systems such as brain, lung, gastrointestinal tract, urinary tract, connective tissue, and skin. A multisystem disorder needs a multidisciplinary approach to care, as treatment interventions permit longer survival for some individuals. Animal models have been developed to help screen treatment options and provide a better understanding of these disorders in the laboratory. Finally, we propose a multidisciplinary approach to promote continued research (both basic and clinical) to improve survival, quality of life, and care for these conditions.
\end{abstract}

Keywords: Menkes disease, kinky hair, ceruloplasmin, neurodegenerative, copper homeostasis

\section{Introduction and historical background}

The focus of this review is to highlight the role a multidisciplinary approach can play in optimizing care of this multisystem lethal disease (Figure 1). The history of Menkes disease (MD) dates back to as early as 1937 when Australian veterinary scientists recognized an association between copper deficiency and a demyelinating disease of the brain in the offspring of sheep grazing in copper-deficient pastures. Researchers in the 1960s observing defective wool in affected sheep turned to the Australian Wool Research Laboratories to establish a link between a copper-deficient diet and defective hair formation. However, efforts to establish a causal relationship between a copperdeficient diet and wool quality remained inconclusive.

In 1962, Menkes et al at Columbia University, New York, NY, USA, described a distinctive clinical syndrome comprising neurological degeneration in five affected male infants of English-Irish heritage who showed unusual hair quality and failure to thrive. These male infants appeared normal at birth through early infancy; subsequently, they developed epileptic seizures and regression of developmental milestones progressing to death between the age of 7 months and 3.5 years. ${ }^{1}$
London Health Science Centre, BI-174

Children's Hospital, 800 Commissioners

Road East, London, ON N6A 5W9,

Canada

$\mathrm{Tel}+\mathrm{I} 5196858814$

Fax +I 5196858625

Email narayan.prasad@lhsc.on.ca 


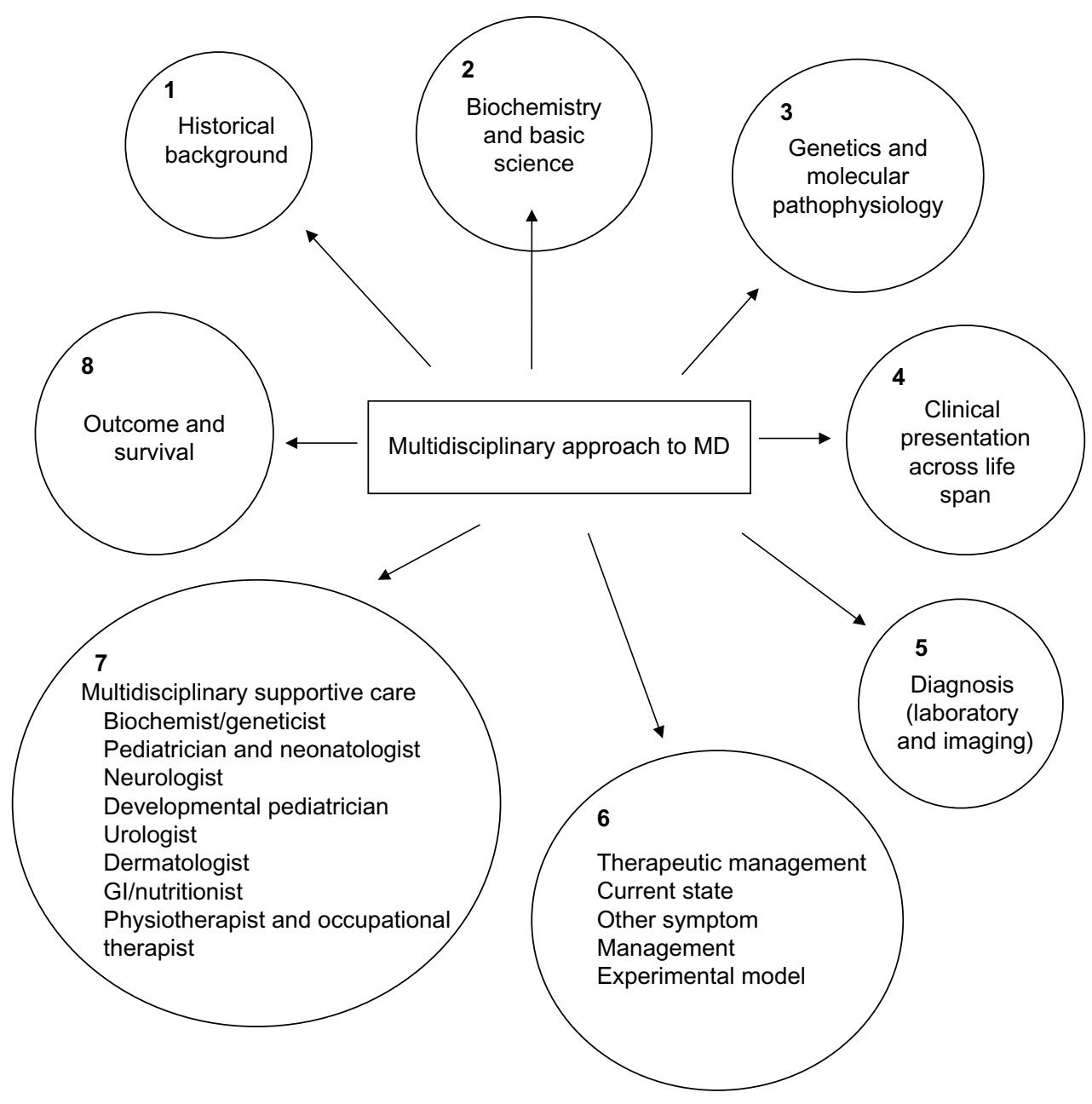

Figure I Multidisciplinary approach to MD.

Abbreviations: Gl, gastrointestinal; MD, Menkes disease.

O'Brien and Sampson ${ }^{2}$ coined the term "kinky hair disease" and performed biochemical studies on frozen brain tissues of two siblings, which demonstrated a reduction in docosahexaenoic acid, the most highly unsaturated fatty acid in brain. Disruption of mitochondrial function was postulated as playing a possible role in this disorder on account of its involvement in fatty acid oxidation.

Danks et $\mathrm{al}^{3}$ reported seven new cases of Menkes kinky hair syndrome from five families seen over a period of 3 years in Melbourne, Australia. The mode of inheritance in each pedigree was compatible with X-linked Mendelian pattern. Hypothermia, developmental delay, growth failure, and very low serum copper were noted along with the unusual hair quality of infants. Hairs from the scalp in these infants appeared sparse, tangled, and lusterless with rotational twists of "pili torti", which were similar in texture to the brittle wool of sheep raised on copper-deficient soil in Australia (Figure 2). Sections of the scalp showed hair follicles deeply buried in the dermis with small, brittle, and broken hair shafts.

$\mathrm{MD}$, as it is currently known, is a lethal X-linked disorder of copper metabolism with multisystem involvement. This disease shows wide variability and clinical heterogeneity in manifestations, ranging from a severe clinical course leading to death in early childhood to a milder form termed occipital horn syndrome (OHS) with connective tissue abnormalities and longer survival. ${ }^{4}$ Patients with MD with intermediate phenotypes $(5 \%-10 \%)$ characterized by later onset and milder symptoms are also described. ${ }^{4,5}$ These variant presentations are being better understood with evolving genotype-phenotype correlations.

Danks et $\mathrm{a}^{6}$ who carried out further research on this disorder used another term, "steely hair disease". A number of other eponyms, such as Menkes steely hair disease, Menkes kinky hair disease, trichopoliodystrophy, and Menkes syndrome, have been used in scientific nomenclature. 


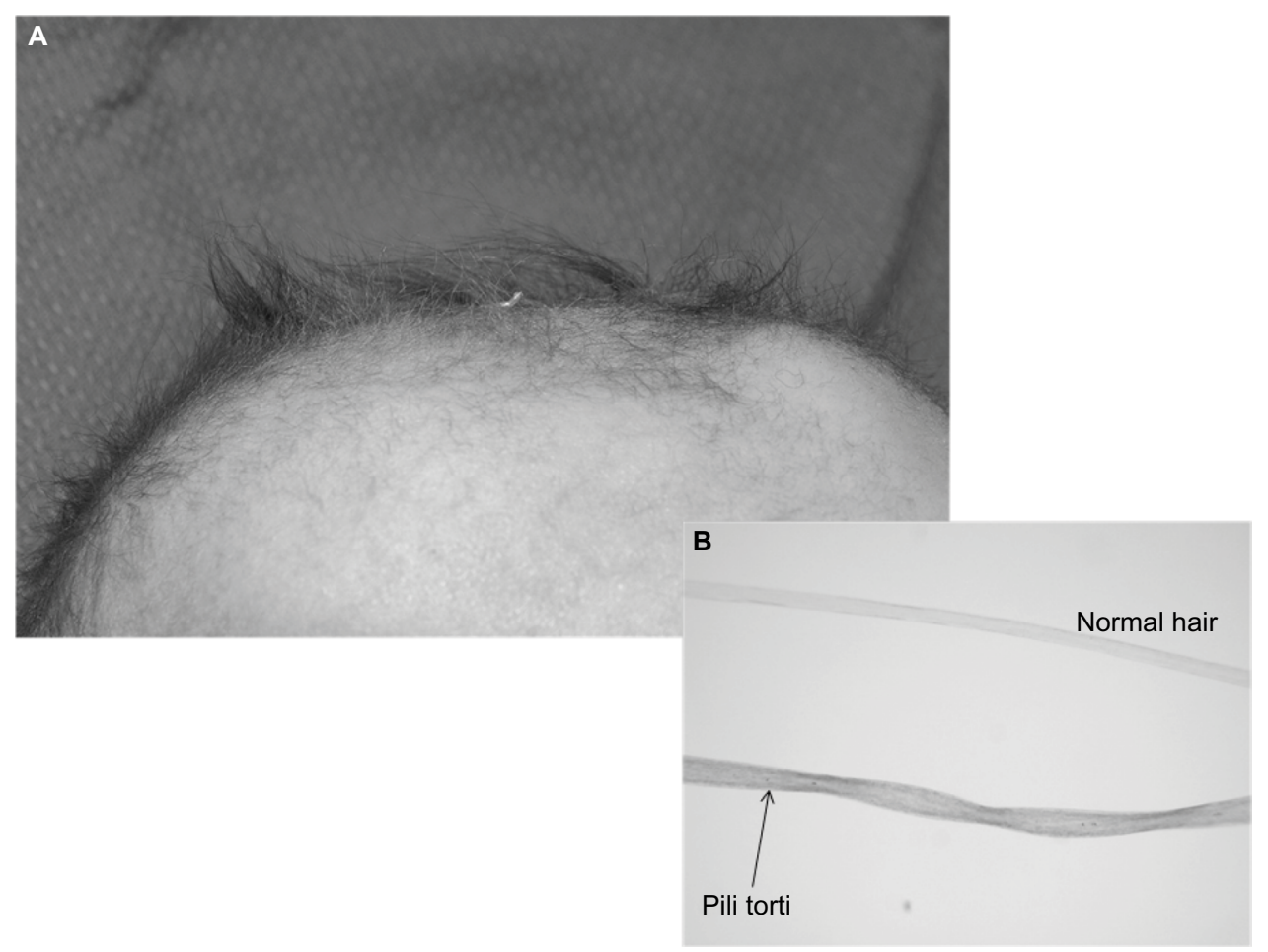

Figure 2 MD: (A) scalp shows "kinky hair", (B) the inset shows "pili torti” and a normal hair strand under a high power microscope. Abbreviation: MD, Menkes disease.

It is important to see how current understanding of different aspects of this disorder has been shaped by developments in the fields of biochemistry, molecular genetics, pathology, clinical presentation, and therapeutic interventions.

\section{Epidemiology}

The overall incidence of MD is reported to be 1 in 100,000 250,000 births. $^{7}$ However, regional geographic variation is recognized. The incidence in Australia is reported to be much higher than elsewhere at 1:50,000-100,000..$^{5} \mathrm{~A}$ large observational study reported the incidence as $1: 300,000$ in Europe and 1:360,000 in Japan. ${ }^{7,8}$ The true incidence rate of OHS is not reported in the literature (to the authors' knowledge), but it is believed to be lower than that of MD. Approximately 35-40 affected individuals are reported in the literature, with the possibility that the condition may be underdiagnosed. ${ }^{9,10}$

The vast majority of patients are male, while biological mothers are heterozygotes or carriers. The population frequency of sporadic cases reported is compatible with the one-third expected for an X-linked lethal disease with equal mutation rates in egg and sperm, which implies a mutation rate of $6.7 \times 10^{-6} /$ gamete/generation. However, the literature reports few affected female patients, with most of them having an $\mathrm{X}$-autosome translocation with a breakpoint at
Xq21.1, truncating ATPA7, which results in clinical manifestations and is attributed to random $\mathrm{X}$ inactivation. ${ }^{4,11} \mathrm{In}$ addition, there are few reports of females with milder symptoms who carry exon deletions (exon 6, 6-9, 1) or base-pair substitutions. ${ }^{12-14}$

\section{Biochemistry}

The liver and kidney are the two organs in mammals that have the highest concentration of copper. ${ }^{15} \mathrm{~A}$ healthy adult body contains $\sim 110 \mathrm{mg}$ of copper, which is distributed in the liver, kidney, brain, blood, and skeletal tissues. ${ }^{16}$ Vegetables, animal proteins, and human breast milk are good sources of copper. ${ }^{17,18}$ Under normal dietary conditions, the gastrointestinal (GI) tract in humans absorbs $\sim 30 \%-40 \%$ of ingested copper. ${ }^{18}$ Copper is present in various GI fluids such as salivary, gastric, pancreatic, duodenal, and bile. The absorption of copper in humans occurs in two phases. ${ }^{15}$ In the first phase, copper is absorbed from the distal small intestine and reabsorbed into the circulation in its protein-bound form to reach the liver and kidney. Once copper enters the body, it is transported to different organs bound to plasma protein carriers (ceruloplasmin, transcuprein, and albumin). ${ }^{19,20}$ In the second phase, copper is transported from the liver (and perhaps kidney) to other organs, including the brain, heart, and skeletal tissue. A small amount of copper is secreted 
Table I Copper enzymes and their role in MD

\begin{tabular}{|c|c|c|}
\hline Enzyme & Biological role & Associated symptoms of MD \\
\hline Cytochrome & Cellular & CNS degeneration, ataxia \\
\hline oxidase & metabolism & Respiratory failure \\
\hline Dopamine & Catecholamine & Hypothermia \\
\hline \multirow[t]{2}{*}{$\beta$-hydroxylase } & production & Hypotension \\
\hline & & Diarrhea \\
\hline \multirow[t]{7}{*}{ Lysyl oxidase } & Collagen and & Cephalohematomas \\
\hline & elastin & Dysmorphic facial features \\
\hline & cross-linking & Emphysema, petechial \\
\hline & & hemorrhage \\
\hline & & Arterial defects \\
\hline & & Skin, bone, and joint \\
\hline & & abnormalities \\
\hline \multirow[t]{2}{*}{ Sulfhydryl oxidase } & Keratin & Bladder diverticula, hernias \\
\hline & cross-linking & Hair abnormalities \\
\hline Super oxide & Free radical & CNS degeneration \\
\hline dismutase & scavengers & \\
\hline Tyrosinase & \multicolumn{2}{|c|}{ Pigment formation Hypopigmentation } \\
\hline
\end{tabular}

Abbreviations: CNS, central nervous system; MD, Menkes disease.

into the bile and is lost via the feces. Most of the copper reaching the liver and kidney is returned to plasma bound to ceruloplasmin, indicating that both organs may be important sources of protein-bound forms of copper in circulation. ${ }^{16}$

Copper is an essential trace element that exists in two different oxidation states, $\mathrm{Cu}+$ and $\mathrm{Cu}++$. These two states play a crucial role in several copper enzyme-dependent metabolic processes. On the one hand, the capability of being able to switch oxidation states is important in metabolic processes, but on the other the same property can result in the release of free radicals adversely impacting cellular events. Therefore, maintenance of cellular homeostasis of copper is vital.

There are various enzymes that require copper for important biological activities within the human body (Table 1). These are cytochrome c oxidase (COX) for cellular respiration; dopamine $\beta$-hydroxylase for biosynthesis of neurotransmitters; lysyl and sulfhydryl oxidase for collagen, elastin, and keratin cross-linking; tyrosinase for pigmentation; and superoxide dismutase for free-radical scavenging. Ceruloplasmin, a key circulating copper-binding protein has a crucial role in the regulation of copper and iron homeostasis. ${ }^{5,21}$ The impact of copper deficiency in the nervous system is significant to the current understanding of neuronal dysfunction at a cellular level and its effects on neuropathogenesis of MD. Low levels of brain copper in MD affect catecholamine pathways, leading to abnormal catecholamine metabolite levels in blood and body fluids. While norepinephrine levels were found to be normal in the infants studied, the ratios of the dopamine metabolites, dihydroxyphenylacetic acid (DOPAC) and the catecholamine precursor dihydroxyphenylalanine, to neuronal metabolite of norepinephrine, dihydroxyphenylglycol (DHPG), were increased above control values, suggesting partial dopamine $\beta$-hydroxylase deficiency. This forms the basis of a newborn screening test, which is discussed in the following sections. Furthermore, a significant reduction in brain COX activity leads to intracerebral lactic acidosis and other mitochondrial abnormalities in MD, which points to insufficiency in cellular bioenergetics as a contributor to neuronal dysfunction.

Gene expression profiling in the single postmortem study of a patient with MD identified dysregulation of 394 genes in the cerebellum and 121 genes in the cerebral cortex. At least 30 genes were found to be common to both the cortex and cerebellum. These genes encode enzymes in the tricarboxylic acid cycle and oxidative phosphorylation (mitochondrial adenosine triphosphate [ATP] synthase), as well as affect ribosomal translation mechanisms, signal transduction, and immune responses. It has also been suggested that the ATP7A protein plays a role in the modulation of excitotoxicity. In vitro studies of mouse models of MD indicate that atp7a-mediated release of copper from an intracellular pool in response to calcium-mediated $N$-methyl-d-aspartate receptor activation is impaired, leaving the neuron vulnerable to excitotoxic injury.

Therefore, in MD, a copper-deficient state is characterized by a multisystem involvement that reflects biochemical perturbation mediated through copper deficiency states that affect enzymatic function involving critical biological processes. The resulting deficits in neurotransmitter function, energy metabolism, and excitotoxicity play key roles in the neurological manifestations of the disease.

\section{Copper metabolism in the cell}

Copper uptake across plasma membrane is dependent on membrane transporter (CTR1). ${ }^{22}$ Copper is bound to various proteins such as metallothionein, glutathione, or copperspecific chaperones that have a role in copper loading of enzymes. ${ }^{23,24}$ Three types of copper chaperones are known: ATOX1, COX 17, and CCS. ATOX1 helps copper to reach the trans-Golgi network, where it is incorporated into two copper-specific ATPases: ATP7A and ATP7B. ${ }^{25}$ Dysfunction of these two ATPases causes MD and Wilson disease, respectively. ATP7A is expressed in almost every organ except liver, while ATP7B is expressed predominantly in the liver. This explains why MD is a systemic disease and Wilson disease is primarily a liver-specific disease with some neurological and ophthalmological involvement. 
Table 2 Functions of ATP7A: a multitasking protein in the nervous system

\begin{tabular}{|c|c|c|}
\hline Function & Evidence & Reference \\
\hline Maintenance of axonal outgrowth and synaptic integrity & Animal model & El Meskini et $\mathrm{al}^{31}$ \\
\hline $\begin{array}{l}\text { ATP7A traffics to hippocampal glutamatergic neurons in } \\
\text { response to NMDA receptor activation. Calcium entry } \\
\text { following such activation is accompanied by copper efflux }\end{array}$ & Animal model & Schlief et $\mathrm{al}^{32}$ \\
\hline $\begin{array}{l}\text { ATP7A participates in the provision of copper to dopamine } \\
\beta \text {-hydroxylase to facilitate conversion of dopamine into NE }\end{array}$ & $\begin{array}{l}\text { Based on CSF neurotransmitter profiles in affected individuals } \\
\text { with MD }\end{array}$ & Kaler et $\mathrm{al}^{33}$ \\
\hline $\begin{array}{l}\text { ATP7A participates in the maintenance of cholinergic neurons } \\
\text { in the peripheral nervous system }\end{array}$ & $\begin{array}{l}\text { Human and yeast models. Unique ATP7A missense mutations } \\
\text { (p.PI386S and p.T994I) in males with distal motor neuropathy } \\
\text { which do not alter the transporters critical functions but } \\
\text { impaired trafficking despite normal ATP7A protein and mRNA } \\
\text { levels. Neuropathy occurs without overt signs of systemic } \\
\text { copper deficiency }\end{array}$ & Kennerson et $\mathrm{al}^{34}$ \\
\hline Angiotensin-II-associated hypertension & $\begin{array}{l}\text { Animal model suggests that angiotensin-Il-induced hypertension } \\
\text { is regulated through extracellular superoxide dismutase SOD3 } \\
\text { activity through the increase in copper delivery via the ATP7A } \\
\text { protein }\end{array}$ & Qin et $\mathrm{al}^{35}$ \\
\hline Cisplatin resistance & $\begin{array}{l}\text { Cell line studies suggest enhancement of cisplatin toxicity in cells } \\
\text { overexpressing ATP7A alone or on pretreatment with } O(6) \text { - } \\
\text { benzylguanine }\end{array}$ & Rabik et $\mathrm{al}^{36}$ \\
\hline Bactericidal activity of macrophages & $\begin{array}{l}\text { Animal model suggesting a role of ATP7A at the host pathogen } \\
\text { interface }\end{array}$ & White et $\mathrm{al}^{37}$ \\
\hline $\begin{array}{l}\text { Hepatic mobilization of copper in the event of a cardiac copper } \\
\text { deficiency }\end{array}$ & $\begin{array}{l}\text { Animal model suggesting a regulatory mechanism for copper } \\
\text { mobilization from the liver to the heart in response to tissue } \\
\text { demand that is mediated through ATP7A protein }\end{array}$ & Kim et $\mathrm{al}^{38}$ \\
\hline
\end{tabular}

Abbreviations: CSF, cerebrospinal fluid; MD, Menkes disease; NE, norepinephrine; NMDA, N-methyl-d-aspartate.

COX 17 directs the copper into mitochondria where other copper metalation proteins such as $\mathrm{COX} 11, \mathrm{SCO} 1$, and $\mathrm{SCO} 2$ are present, ${ }^{26}$ while CCS directs copper to superoxide dismutase, which resides in the cytosol or the mitochondria. ${ }^{27}$ ATP7A and ATP7B have important roles in ATP-driven cellular efflux of copper as described in the following section. ${ }^{28}$

\section{Regulation of copper transport}

The ATP7A mRNA is expressed in several human tissues, but is notably low or absent in the liver, while the ATP7A gene product is a transmembrane protein localized to the Golgi network. Under normal physiological conditions where the copper concentration in the body is normal, ATP7A remains confined within the trans-Golgi network and continues to transport copper to the copper-dependent enzymes. However, when total intracellular copper stores increase, ATP7A relocates to the cell membrane to promote copper efflux..$^{29,30}$ At the blood-brain barrier, ATP7A tends to traffic to the basolateral membrane promoting delivery of copper from blood to the brain, while in certain specialized epithelial cells such as the choroid plexus, the protein localizes to the apical membrane. Once copper reaches the cerebrospinal fluid, it forms complexes with albumin and amino acids (histidine). It is then imported into neurons through specific copper importers (DMT1 and CRT1) and delivered through metallochaperones to ATP7A and ATP7B, eventually participating in the metalation of cuproenzymes.

ATP7A is a multitasking protein that is involved in a multitude of functions ranging from axonal outgrowth, synaptic integrity, responses to $\mathrm{N}$-methyl-d-aspartate receptor activation, and other functions as listed in Table 2.

\section{Molecular genetics}

Early studies in understanding the genetics of MD came through the identification of a defect in copper metabolism. ${ }^{39}$ Copper concentrations were elevated in the cultured fibroblasts of affected males and heterozygote carriers. Similarities between the clinical and biochemical phenotype in humans and the "mottled" mouse (Mo) and the knowledge that mottled gene mutations were close to the phosphoglycerate kinase (PGK) gene, which in humans is located on the $\mathrm{X}$ chromosome, led to the conclusion that the gene for MD was likely located on the $\mathrm{X}$ chromosome. Further, linkage studies using restriction fragment length polymorphism markers in a large kindred and studies on a female patient with both this disease and an X-autosome translocation with karyotype 46, $\mathrm{X}, \mathrm{t}(\mathrm{X} ; 2)(\mathrm{q} 13 ; \mathrm{q} 32.2)$ indicated that the Menkes gene maps to a small subregion of band Xq13.2-q13.3 proximal to the PGK1 locus ${ }^{40}$ which was also confirmed by additional finemapping studies ${ }^{41} \mathrm{~A}$ yeast artificial chromosome clone was 
isolated spanning the breakpoint region, and cDNA libraries were scanned using phage subclones from the breakpoint region. An $8 \mathrm{~kb}$ transcript from a gene at the breakpoint showed diminished hybridization in patients with MD. Partial sequencing identified metal-binding motifs supporting the likelihood that this was indeed the candidate gene. The ATP7A gene is located at the chromosome locus Xq13.3 and has eight transmembrane segments and six copper-binding sites/domains, additional domains for phosphatase, phosphorylation, transduction, and ATP binding.

Using restriction enzyme mapping, exon identification, and sequencing techniques, 23 exons were identified spanning a $140 \mathrm{~kb}$ region as well as the intron-exon boundaries defining the ATP7A gene. The gene was found to bear a strong sequence homology at the 3 ' region with the Wilson disease (Wnd) gene and divergence for a third of the gene at the $5^{\prime}$ region, suggesting a common ancestral origin from an evolutionary perspective. Further characterization of the candidate gene for Menkes $(M N K)$ disclosed that the gene codes for a 1,500 amino-acid protein, which is predicted to be a P-type cation-transporting ATPase (ATP7A) similar to a bacterial copper-transporting ATPase. ${ }^{42-44}$

Most of the clinical phenotypic features were already attributable to malfunction of copper-containing enzymes that were deficient in copper, and cell studies from patients with MD had already been demonstrated to accumulate increased amounts of copper attributable to a reduced efflux of the copper ion. These findings were in line with the discovery of the candidate gene product bearing a homology to heavy metal-binding ATPases in bacteria and man. With these discoveries, MD has come to be understood as a disorder of copper homeostasis.

\section{Genotype-phenotype correlations}

Pathogenic mutations in $A T P 7 A$ result in a variety of clinically recognizable phenotypes associated with copper transport disorders (MD, OHS, and the ATP7A-related distal motor neuropathy). The degree to which residual ATP7A function is maintained determines the severity of the clinical phenotypes. Mutations of every variety have been associated with MD; the majority are de novo and private. Exon deletions can be detected by the multiplex ligation-dependent probe amplification as an initial DNA test, while smaller intragenic mutations can be examined by polymerase chain reaction amplification and sequencing of coding exons using genomic DNA.

More than 311 different mutations have been reported in patients with MD. ${ }^{45}$ Deletions or insertions $(22 \%)$, large gene deletions (22\%), duplications, missense (17\%), nonsense (18\%), and splice junction mutations (18\%) have all been described. A 700-nucleotide region involving exons 7-10 seem to be associated with a significant proportion of pathogenic mutations resulting in MD. ${ }^{46-48}$ Those mutations that result in a severe truncation of the gene product and significant loss of function likely result in MD; hypofunctional splice site resulting from aberrant splicing and missense mutations with retention of protein function are associated with milder phenotypes. With $0 \%-15 \%$ residual function in ATP7A activity, the resulting phenotype is $\mathrm{MD}$; higher degrees of function up to $30 \%$ result in the milder OHS phenotype, while $60 \%-70 \%$ residual function is associated with late-onset distal motor neuropathy. ${ }^{49}$

Although the majority of affected individuals are males, heterozygous females tend to be carriers based on skewed inactivation of the $\mathrm{X}$ chromosome; rarely females with chromosomal translocations have been reported to be affected and manifest symptoms.

Of all the different mutations described, ${ }^{50}$ two mutations resulting in $\mathrm{MD}$ are amenable to early treatment with copper (Gly666Arg and Gly727Arg). Not much is known about the treatment response of remaining missense mutations.

The OHS is an allelic disorder of MD that results from exon skipping and aberrant splicing, although missense mutations without aberrant splicing are also described. Less frequently, deletions affecting the promoter region or resulting in a leaky "splice junction" may also lead to the milder OHS phenotype. The mutations seem to result in a significantly greater degree of retention of ATP7A activity than those leading to MD.

The third phenotype of ATP7A-related distal motor neuropathy is distinctive in that there are no overt copperrelated metabolic/biochemical abnormalities. The mutations underlying this phenotype are missense mutations affecting amino acids within or near transmembrane segments of the protein. The resulting amino acid substitutions appear to affect trafficking of the protein to distal axons and the resulting deficiency of copper-dependent enzymes critical to the maintenance of integrity and function of the motor neuron and its axons. The precise mechanism underlying the pathophysiology of this unique disorder of copper transport and metabolism remains to be elucidated. ${ }^{51-54}$

\section{Clinical presentation of MD}

The key clinical features of classical MD, intermediate forms, and OHS are summarized in Table 3. 
Table 3 Manifestations of MD

\begin{tabular}{|c|c|c|c|}
\hline $\begin{array}{l}\text { Symptoms and laboratory } \\
\text { findings in MD }\end{array}$ & Classical & Intermediate & OHS \\
\hline \multicolumn{4}{|l|}{ Clinical } \\
\hline Facial dysmorphism & + & \pm & + \\
\hline \multicolumn{4}{|l|}{ Neurological abnormalities } \\
\hline Intractable seizures & ++ & - & - \\
\hline Dysarthria & - & ++ & \pm \\
\hline Ataxia & - & ++ & + \\
\hline Developmental delay & ++ & \pm & \pm \\
\hline Hypotonia & ++ & + & \pm \\
\hline \multicolumn{4}{|l|}{ Dermatological abnormalities } \\
\hline Hair abnormalities & ++ & + & \pm \\
\hline Hypopigmented skin & + & + & - \\
\hline Cutis laxa & + & + & ++ \\
\hline $\begin{array}{l}\text { Bony changes (osteoporosis, rib } \\
\text { fracture, wormian bone in skull) }\end{array}$ & ++ & + & + \\
\hline Hypothermia & + & \pm & \pm \\
\hline Bladder diverticula & + & + & + \\
\hline Recurrent UTI & + & + & + \\
\hline Diarrhea & + & + & + \\
\hline GORD, polyp, hiatus hernia & + & $?$ & $?$ \\
\hline Retinal degeneration & + & $?$ & $?$ \\
\hline \multicolumn{4}{|l|}{ Biochemical } \\
\hline $\begin{array}{l}\text { Low serum copper and } \\
\text { ceruloplasmin }\end{array}$ & + & + & + \\
\hline $\begin{array}{l}\text { Abnormal plasma/CSF } \\
\text { catecholamines }\end{array}$ & + & $?$ & $?$ \\
\hline \multicolumn{4}{|l|}{ Radiological } \\
\hline $\begin{array}{l}\text { X-Ray skull: presence of wormian } \\
\text { bones }\end{array}$ & ++ & - & - \\
\hline $\begin{array}{l}\mathrm{CT} / \mathrm{MRI} \text { changes in brain: global } \\
\text { cerebral atrophy, cerebellar } \\
\text { atrophy, focal changes in } \\
\text { temporo-occipital, frontal } \\
\text { parietal lobes, subdural effusion, } \\
\text { leukoencephalopathy, and abnorma } \\
\text { vasculature }\end{array}$ & ++ & \pm & \pm \\
\hline Tortuosity of intracranial vessels & ++ & $?$ & $?$ \\
\hline
\end{tabular}

Notes: ++ is very much likely; + is likely; - is not likely; +/- may or may not be likely; ? is questionable.

Abbreviations: CSF, cerebrospinal fluid; CT, computed tomography; GORD, gastro-oesophageal reflux disease; MD, Menkes disease; MRI, magnetic resonance imaging; OHS, occipital horn syndrome; UTI, urinary tract infection.

\section{Classical form of MD}

Pregnancy and labor are usually uncomplicated, and most affected males born with MD have normal anthropometric measures at birth. However, early features noted with these neonates are: hypothermia, cephalohematomas, persistent hyperbilirubinemia, hypoglycemia, and feeding difficulties. ${ }^{30,55,56}$ Such infants are also recognized to carry subtle dysmorphic facial features such as frontal or occipital prominence, pudgy cheeks with broad nasal bridge, and micrognathia and often may appear dull and expressionless. ${ }^{55}$ Various types of congenital malformations are known to be associated with MD. In one study, 35 patients with MD were reviewed and 14 were found to have congenital malformations. Out of these 14 patients, eight had minor congenital malformations including high arched palate, micrognathia, congenital microblepharia, entropion, and a flat occiput. The remainder had major congenital malformations including cerebellar hypoplasia, cystic white-matter changes in the brain, congenital complete $\mathrm{A}-\mathrm{V}$ block, and cystic changes in the arachnoid membranes in the lungs. ${ }^{57}$

Respiratory infections such as pneumonias are reported in the literature as one of the causes of severe morbidity or mortality in MD. ${ }^{58,59}$ An anecdotal report of a 19-month-old male infant who died of MD revealed, at necropsy, bilateral diffuse panlobular emphysema in the lungs ${ }^{60} \mathrm{~A}$ similar case is also reported in an infant presenting with respiratory illness from the age of 9 months, in whom chest radiography revealed progressive generalized hyperinflation and increased cystic spaces. An autopsy at 14 months showed severe diffuse panlobular emphysema with large bullae along with abnormal pulmonary vascular development. ${ }^{56}$ The authors hypothesized that deficiency of the copper-dependent enzyme, lysyl oxidase, leads to abnormalities in quality and quantity of elastin, which forms an important element in connective tissue formation, leading to aneurysmal dilatation and emphysema in MD.

GI manifestations in MD are reported infrequently, and there may be an under-recognition of involvement of the GI tract. Gastric polyps, gastroesophageal reflux disease, and colonic diverticula are reported in the literature. .6,61,62 $^{56}$ Hiatus hernia has been reported to be associated with MD and OHS. ${ }^{63,64}$ Progressive sliding hiatus hernia was noted in a 19-month-old male infant with MD, which progressed rapidly, requiring surgical intervention. ${ }^{63}$ An additional two infants with MD have been described in whom severe GI bleeding secondary to gastric polyps was noted. One of these patients died of severe hemorrhage. ${ }^{65}$ In addition to GI manifestations, an unusual presentation of MD with hepatomegaly in a 4-month-old infant who was known to carry a missense mutation of his ATP7A gene (Gly727Arg mutation) has also been reported. The liver biopsy revealed nonspecific cholestasis and focal necrosis. ${ }^{66}$

Several connective tissue abnormalities are described in $\mathrm{MD}$, which are considered to be secondary to reduced activity of lysyl oxidase, a copper-dependent enzyme important for cross-linking collagen and elastin. ${ }^{67,68}$ These include pectus excavatum, pectus carinatum, the presence of wormian bones in skull, osteopenia, and spontaneous fractures of long bone. ${ }^{59}$ Most patients with MD have mottled hypopigmented and pale skin presumably due to tyrosinase deficiency. ${ }^{69}$ 
The scalp hairs (Figure 2) may appear normal at birth, but by 2-3 months of age they become kinky, coarse, sparse, brittle, and hypopigmented, which are characteristic of MD. ${ }^{70,71}$ Microscopic examination of the hair reveals various abnormalities and even aids in the diagnosis of milder form of the disease. ${ }^{72}$ Several hair shaft abnormalities have been reported, with pili torti (twisted hair) being the most common; trichorrhexis nodosa (fracture of the hair shaft at regular intervals), monilethrix (varying diameter of hair shafts), trichoclasis (hairs are broken off from $6 \mathrm{~mm}$ to $8 \mathrm{~mm}$ from the skin), and trichoptilosis (splitting of the shaft of the hair) have also been reported. ${ }^{72,73}$

The neurological manifestations of MD are also varied. Epileptic seizures are one of the most common and wellrecognized features of MD. Most patients develop treatmentresistant forms of seizures by $\sim 2-3$ months of age. ${ }^{74,75}$ Many different kinds of seizures have been described in affected infants and children with MD. Seizures in MD can be triggered by the acute stress secondary to severe infection, a febrile event, or could be preceded by nonconvulsive seizures associated with recurrent episodes of apnea. ${ }^{76-79} \mathrm{~A}$ case series (Bahi-Buisson et al) focused on electroclinical features in MD and described the natural progression of epilepsy in MD; the key features are summarized in Table 4.

Seizures and neurological regression usually become apparent at 6-8 weeks of life. Three stages are identified in the natural history of the progression of epilepsy in MD. Electroencephalography (EEG) abnormalities may antedate the appearance of seizures, as early as 2 months of life. The three stages are as follows: 1) an early stage at the age of 3 months with focal seizures progressing to status epilepticus, 2) an intermediate stage (6-11 months) where epileptic spasms, including West syndrome accompanied by EEG changes of hypsarrhythmia, develop; myoclonic seizures as a presenting symptom have also been reported, and finally, 3) a third late stage that is characterized by the emergence of multifocal seizures, tonic spasms, and myoclonus encountered in infants with a mean age of $\sim 20-25$ months. ${ }^{78,80,81}$ Typical interictal and ictal EEG findings are described in an earlier article ${ }^{78,81}$ (Figure 3).

EEG abnormalities correlate with molecular defects, as shown in a series of 24 patients with MD, where patients with missense and leaky splice junction mutations were found to have normal EEGs. On the other hand, large deletions, small deletions, nonsense mutations, and canonical splice junction mutations were associated with significant EEG abnormalities in $>50 \%$ of the cases. ${ }^{47,74}$

Presymptomatic diagnosis and early treatment may improve brain electrical activity. This was demonstrated in a study which looked at 24 patients with MD. In that study, the authors reported that patients were started on copper supplementation soon after the diagnosis ( $\leq 6$ weeks of age) and they noted clinical seizure in only $12.5 \%$ of the patients, and they found that $46 \%$ had at least one abnormal EEG tracing. ${ }^{81}$ Early diagnosis and treatment are closely correlated with the genesis of epilepsy in MD. A study in 2008 demonstrated that copper replacement within 22 days of life in 12 newborns diagnosed with MD had improved the clinical outcome. ${ }^{82}$

Neuropathologic changes in MD are also distinct. There is diffuse cerebral and cerebellar atrophy that is a consequence of volume loss of both white and gray matter. Widespread histological abnormalities noted include neuronal loss and gliosis within cortical gray matter, cystic infarction in the basal ganglia, loss of Purkinje cells in cerebellum, and spongy changes in cerebral white matter along with loss of myelin sheaths and axons. ${ }^{83,84}$ The muscle shows ragged red fibers on histology, with pleomorphism of mitochondria and cristae under the electron microscope. ${ }^{82}$ Vascular abnormalities are noted in the cerebral arteries; these vessels appear thin walled, ectatic, and tortuous ${ }^{59,84}$ (Figure 4).

Table 4 Evolution and progression of epilepsy in MD

\begin{tabular}{|c|c|c|c|c|}
\hline Epilepsy course (stage) & Type of seizure & Median age & EEG findings & Outcomes \\
\hline Early & $\begin{array}{l}\text { Focal clonic and } \\
\text { status epilepticus }\end{array}$ & 3 months & $\begin{array}{l}\text { Ictal EEG showed slow spike wave and slow } \\
\text { wave in posterior region; interictal EEG showed } \\
\text { multifocal and polymorphic slow waves or mixed } \\
\text { slow wave spikes }\end{array}$ & $\begin{array}{l}\text { Partial seizure control in } \\
\text { nine of the } 12 \text { patients }\end{array}$ \\
\hline Intermediate & $\begin{array}{l}\text { Intractable infantile } \\
\text { spasm }\end{array}$ & 10 months & $\begin{array}{l}\text { Modified hypsarrhythmia; different irregular slow } \\
\text { waves and spike waves }\end{array}$ & $\begin{array}{l}\text { Six patients died at a } \\
\text { median age of } 15 \text { months }\end{array}$ \\
\hline Late & $\begin{array}{l}\text { Multifocal, myoclonic } \\
\text { seizure and tonic } \\
\text { spasm }\end{array}$ & 25 months & $\begin{array}{l}\text { Multifocal high-amplitude activity; mixed irregular } \\
\text { slow waves }\end{array}$ & $\begin{array}{l}\text { The remaining six } \\
\text { patients died at a median } \\
\text { age of } 3.6 \text { years }\end{array}$ \\
\hline
\end{tabular}

Note: Data adapted from Bahi-Buisson et al. ${ }^{78}$

Abbreviations: EEG, electroencephalography; MD, Menkes disease. 


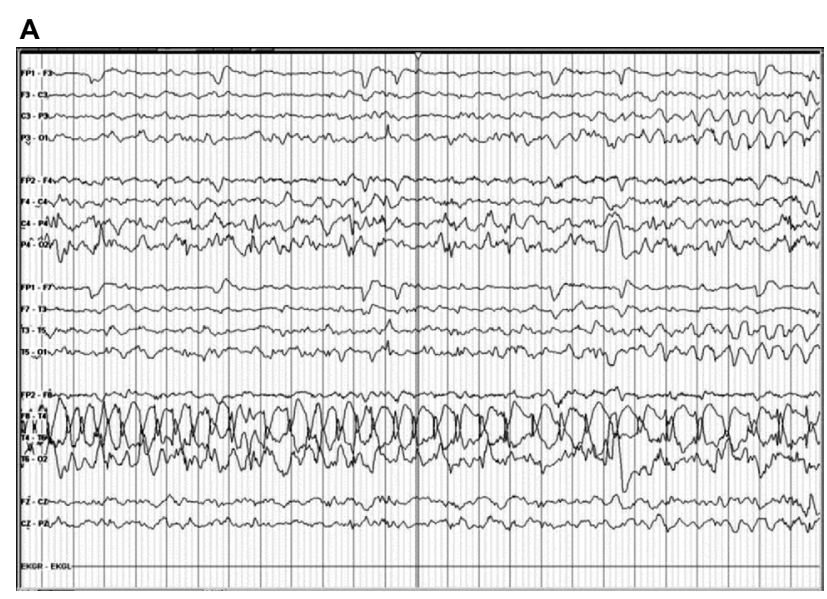

B

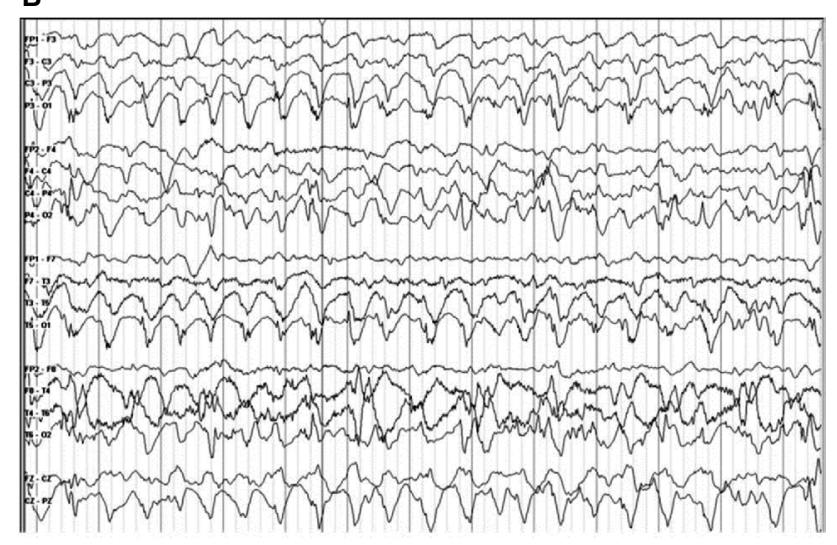

C

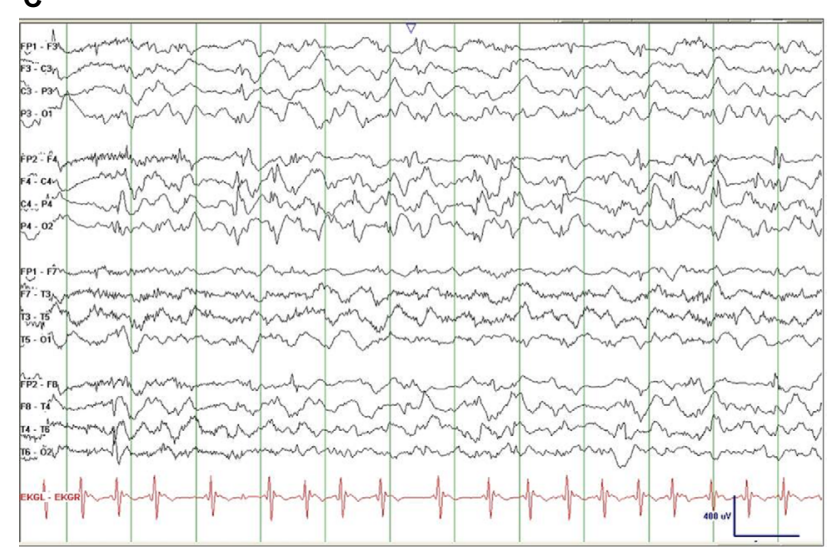

Figure 3 EEG segments from patient with MD.

Notes: (A) Anterior-posterior bipolar montage shows ictal rhythm corresponding to a focal seizure originating in the right mid to posterior temporal regions (I5 mm/s, sensitivity at $15 \mu \mathrm{V} / \mathrm{mm}$ ). (B) Ictal rhythms showing rhythmic generalized spike and slow waves (time base at $30 \mathrm{~mm} / \mathrm{s}$, sensitivity at $20 \mathrm{IV} / \mathrm{mm}$ ). (C) Late stages - interictal background rhythms are slow for age, with multifocal independent spikes and spike and wave complexes (time base at $30 \mathrm{~mm} / \mathrm{s}$, sensitivity at $20 \mathrm{IV} / \mathrm{mm}$ ).

Abbreviations: EEG, electroencephalography; MD, Menkes disease.

\section{Occipital horn syndrome}

OHS is considered to be the mildest form of MD with a few male patients with overlapping features of classical and/or mild MD and OHS reported ${ }^{85}$ Patients with OHS have very similar presentations as with MD at birth, such as hypothermia, jaundice, and feeding difficulties. In addition, they may present with umbilical and inguinal hernias. The findings in contrast to classical MD are connective tissue abnormalities such as, wrinkled, loose skin and bony abnormalities of flat and long bones, including osteoporosis. The distinct radiologic feature of OHS is symmetric exostoses protruding from occipital bones, leading to the designation of "occipital horn". The diagnosis of OHS is often delayed until 5-10 years of age due to milder and subtle symptoms. Usually, the early signs that bring these patients to medical attention are intractable diarrhea and recurrent urinary tract infection, which are secondary to bladder diverticula. Intellectual capabilities in these patients are described as low to borderline normal. Motor development is also delayed secondary to muscular hypotonia and other connective tissue disorders. Patients with OHS can remain alive until adulthood. ${ }^{5,86}$

\section{Intermediate forms}

Between classical MD and OHS lies another group of disorders that is a milder form of MD with late presenting symptoms. ${ }^{87}$ These patients have abnormal hair (pili torti), variable connective tissue manifestations such as lax skin and joints, and characteristic facial features. They are also reported to have milder neurological presentations compared to MD and commonly have ataxia, dysarthria, and mild intellectual disabilities. ${ }^{88,89}$

\section{Diagnosis}

Early diagnosis of MD is challenging because clinical features and biochemical markers may be nonspecific and unreliable. Clinical presentations such as hypothermia, hyperbilirubinemia, and feeding difficulties are nonspecific and may present in neonates with other conditions such as sepsis. Serum copper and ceruloplasmin levels may be low in normal healthy newborns and hence not a good predictor in the early diagnosis of MD. Molecular analysis confirms the diagnosis. There are $>300$ different mutations reported in MD, which include missense and nonsense mutations along with deletion and insertions of one or more base pairs leading to frameshift and splice site mutations. ${ }^{90-92}$

\section{Newborn screening}

Currently, there are no newborn screening programs that are routinely screening for MD in countries where newborn screening programs exist for other genetic/metabolic disorders. However, a role for newborn screening can be rationalized on the basis of the evidence that early diagnosis 


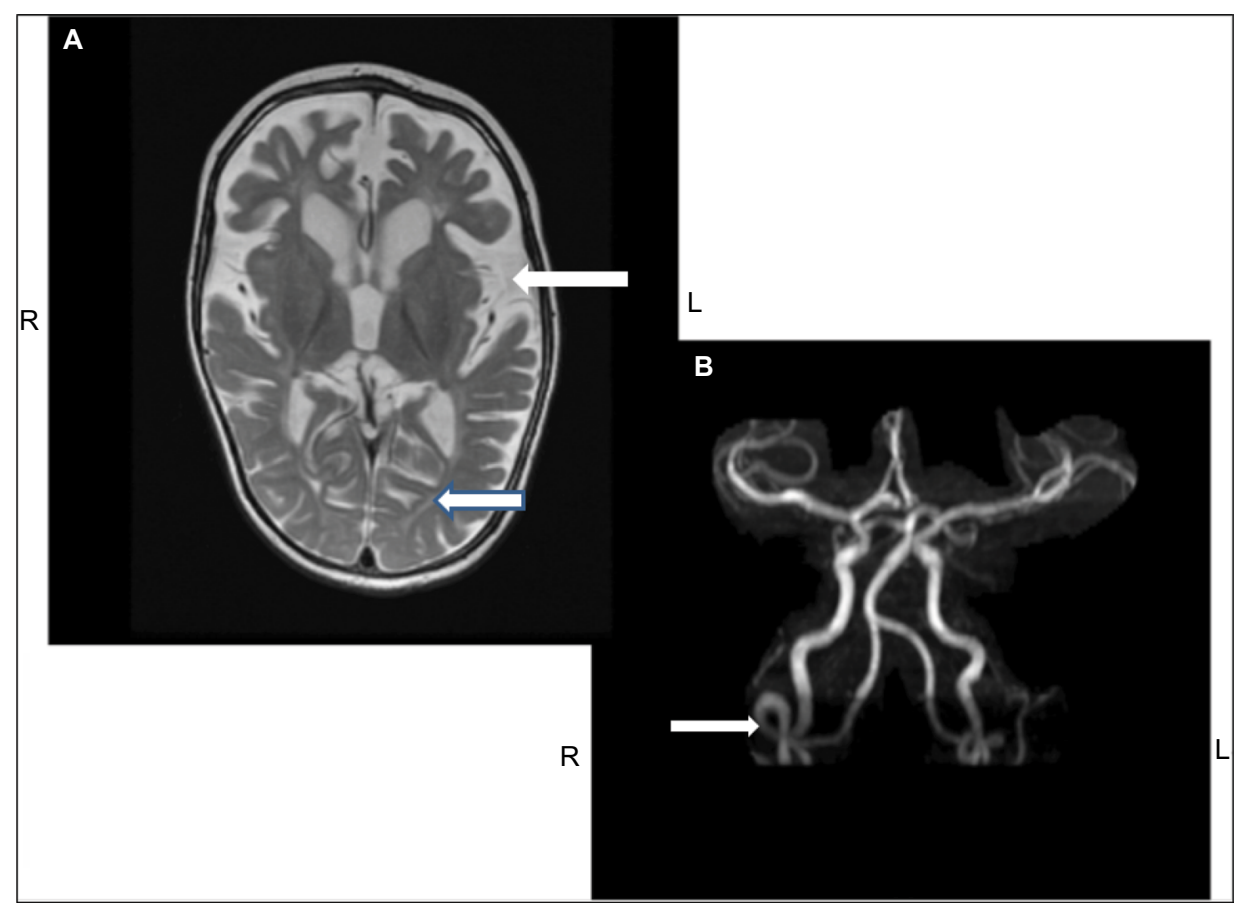

Figure $4 \mathrm{MRI}$ of the brain (A) and MRA (B) from the same patient.

Notes: (A) Generalized fronto-temporal cerebral atrophy resulting in exposure of the insula, and thinning of the subcortical white matter (arrows). (B) Tortuosity of intracranial vertebral arteries (arrow).

Abbreviations: L, left; MRA, magnetic resonance angiography; MRI, magnetic resonance imaging; $R$, right.

seems to make a difference in survival and outcome in some patients with MD. ${ }^{82}$ Measurement of neurochemicals such as dopamine, norepinephrine, DOPAC, and DHPG in the plasma and cerebrospinal fluid is reported to be highly specific and sensitive test to diagnose MD in the early neonatal period. The ratio of DOPAC to DHPG reflects the deficiency of dopamine $\beta$-hydroxylase activity. ${ }^{82,93}$

An argument can thus be made for the inclusion of MD into neonatal screening programs based on the detection and measurement of plasma dopamine, norepinephrine, DOPAC, and DHPG using blood dot specimens.

\section{Prenatal diagnosis}

Prenatal diagnosis is available for women who are MD carriers, by chorionic villus sampling and analyzing copper uptake in cultured fibroblasts in pregnancies at high risk, and where the mutation is unknown. If there is an affected individual in the family with a known mutation, then the pathogenic mutation can be identified through mutation analysis. ${ }^{94,95}$

\section{Animal models}

Much of our understanding about MD stems from animal models. ${ }^{96}$ Early studies have focused on the mottled mouse that carries mutations in the Atp 7 a gene resulting in a mottled coat in heterozygous females. The murine gene locus Atp7a and the human homolog ATP7A are located on the X chromosome, and share $>80 \%$ homology. Both gene products on sequence alignment show highly conserved amino acid sequences within functional domains. ${ }^{97}$ These similarities extend to the ATP7A proteins in zebrafish and fruitfly. The initial description of the mottled mouse appeared in $1953,{ }^{98}$ and the defects in copper transport were described in these mutant mice by Hunt in $1974 .{ }^{99}$ Currently, 109 mottled alleles are known in the Mouse Genome Informatics database. These have arisen spontaneously or by chemical, radiation, or targeted mutagenesis. Phenotypic severity in these models involving male mice varies from lethality in utero and death in 3 weeks to mice that survive a few postnatal months. A detailed assessment of these mutants is beyond the scope of this review. The reader is referred to an outstanding review on the subject. ${ }^{97} \mathrm{It}$ is however important to summarize important insights that have been gained. Mutations that confer embryonic lethality completely abolish residual protein activity, suggesting a critical role for copper in embryogenesis. "Brindled", "mosaic", and "macular" are strains that have been studied, and mutations in this group are missense or in frame deletions that lead to reduced synthesis of the mutant protein with reduced residual activity. Hemizygous males show characteristic features of severe copper deficiency, but survive beyond 3 weeks of postnatal life. Mutants that include "viable brindled" and "blotchy" survive a 
few months and develop features of atypical MD and/or OHS particularly connective tissue abnormalities. Aortic aneurysms (viable brindled), emphysema, osteoarthrosis, abdominal aneurysms (mottled), infertility (common to both mutants), and hypopigmentation are among the features shared between the models and human disease.

These mice have also served as models for exploring treatments. Copper replacement therapy given early to mottled mice improves survival, and the combination therapy with a copper chelator diethyldithiocarbamate has shown promising results. ${ }^{100-102}$ Treated animals showed improved survival, increased copper levels in the brain, improved locomotion, and greater body mass.

Transgenic mice models have also been developed from the brindled strain, where human $A T P 7 A$ was expressed in a truncated form using recombinant adenovirus encoding the truncated gene that was administered by intraventricular injections. The treated mice survived longer and demonstrated higher dopamine monooxygenase activity in the brain along with improved neuromuscular strength and balance.

Mottled mice have also proven invaluable in studying the interaction between copper and iron metabolism suggesting intricate linkages that impact hematopoiesis and red cell turnover.

Other animal models include the zebrafish (Danio rerio) and the fruitfly (Drosophila melanogaster). In the zebrafish, calamity mutants generated by chemical mutagenesis have served as novel vertebrate models of MD. ${ }^{103}$ The phenotypic effects extend to lack of pigmentation and defects of the notochord. Morpholinos (oligonucleotides that can target RNA sequence of interest) can correct aberrant splicing in the embryonic calamity mutant zebrafish and effect a rescue by leading to the production of normal Atp7a protein as in the wild type. ${ }^{104}$

The fruitfly has been studied as a model for many neurodegenerative disorders. A null mutation in the DmATP7 gene has resulted in a classical model for MD. ${ }^{105}$ The mutant fruitfly is extremely lethargic, while larvae are small and hypopigmented. Another model using conditional silencing of DmATP7 only in the digestive tract results in enhanced lethality and 50\% survival to adulthood. The survivors show small brain size, but normal morphology as far as pigmentation is concerned. They are also sensitized to oxidative stress, a feature of MD that has been attributed to reduced superoxide dismutase activity. ${ }^{106}$

Animal models can thus be used to develop therapeutic approaches through genetic modification as well as screening of compounds that affect copper metabolism.

\section{Management}

MD is a fatal disorder with death usually occurring between 6 months and 3 years of age as a result of neurological deterioration, poor feeding, aspiration, or respiratory infections. Those patients with less severe disease have a better survival rate with copper supplementation; however, the outcome depends on the severity of the ATP7A mutation and the residual function of ATP7A protein. Treatment with copper supplementation is most likely effective in those cases where the mutated protein retains the ability to transport copper across the blood-brain barrier. In patients with MD where the mutation leads to severe disease, treatment is ineffective. ${ }^{82}$ Although treatment has not yet been known to reverse the neurological damage, a small subgroup of patients with MD manifesting milder symptoms have been reported to have better outcome. ${ }^{107}$

There have been few reports of long-term survival with MD. Tchan et al ${ }^{108}$ reported a patient with MD at 34 years having received copper supplementation for $>30$ years and having only mild intellectual impairment. Another patient with MD receiving copper supplement was reported to have survived till the age of 13.5 years. ${ }^{109}$

Parenteral copper administration is considered the mainstay in treatment protocols for MD as oral preparations are not shown to be effective. Most researchers have used copper histidinate for treating MD. ${ }^{110,111}$ Subcutaneous administration of copper histidinate can normalize circulating blood levels of copper and ceruloplasmin and may replete brain copper. ${ }^{112}$

Prasad et $\mathrm{al}^{113}$ reported the correction of biochemical markers in a patient with MD using subcutaneous cupric chloride. They reported restoration of serum copper and ceruloplasmin along with clinical improvement in skin color and quality of hair; however, neurological status did not improve.

Early screening and prompt medical intervention are crucial in MD. Patients who were diagnosed and received early treatment with copper (within 25 days) had a much better neurodevelopmental outcome compared to late onset of treatment (228 days). ${ }^{114} \mathrm{Kaler}^{112}$ conducted a clinical trial using copper histidinate for MD, looking at somatic growth and neurodevelopmental outcome in 60 patients. The findings in this trial suggested that those who received copper histidinate before the onset of symptoms showed significant improvements in gross motor, fine motor/adaptive, personalsocial, and language development in comparison to those who were symptomatic at the time of diagnosis. The mortality rate at the age of 3 years was also reported to be higher in the symptomatic group. ${ }^{112}$ Other studies have also reported similar outcomes. ${ }^{115,116}$ Christodoulou et $\mathrm{al}^{111}$ reported improvement in 
muscular tone and seizure activities in four patients with MD who they followed as a result of early treatment with copper histidine for 10-20 years. However, the response to connective tissue abnormalities associated with MD was noted to be poor.

\section{Multidisciplinary approach to MD}

$\mathrm{MD}$ is a multisystem disorder that has no cure. Current published data on MD suggests that there is wider age dependent variability in phenotypes at presentation. ${ }^{54}$ However, contrary to previous notions of shortened life expectancy, patients currently seem to have better outcomes in terms of survival. A multidisciplinary approach can improve the quality of life and holistic care for patients with MD (Table 5).

Neonatal nurses or neonatologists can play an important role in the early recognition of subtle signs and symptoms such as hypothermia, unusual hair, and dysmorphic facial features. This can facilitate early referral and diagnosis, supporting the initiation of copper supplementation as required. Outside the neonatal unit, nurses or doctors in clinics or in the emergency department can come across this disorder. Children may present with macrocephaly with subdural hematoma, occasionally mimicking a diagnosis of shaken baby syndrome, needing further evaluation. ${ }^{117}$ Patients with MD may also present with macrocephaly and seizures closely simulating neurological disorders such as leukodystrophies and Canavan or Alexander diseases ${ }^{118,119}$ prompting early referral to pediatric neurologists and genetic metabolic specialists. These patients may also present to developmental or neurology clinics with a history of delayed or regressing milestones.

Interventions involve the institution of copper replacement therapy and the potential use of chaperones in the future. Failure to thrive should be assessed by a feeding team in association with a dietitian who can provide a feeding plan to optimize growth. Occupational therapists and physiotherapists can provide detailed assessment and management strategies for those patients who have problems with their tone and mobility. These can include a range of movement exercises, ways to prevent contractures and bedsores as well as assisting in formulating plans for activities of daily living.

Parents of patients with MD can benefit from education on how to give injections and take care of the patients at home. Anticipatory guidance about creating a safe environment, medications to alleviate symptoms, and supportive interventions for seizure management can be provided through nurse educators.

Genetic counselors have a role in providing parental reproductive risk counseling and prenatal diagnosis. Parents benefit through the sharing of information through support groups and social media connectivity. It is often noted that families taking care of patients with very high needs face
Table 5 Multidisciplinary management in MD

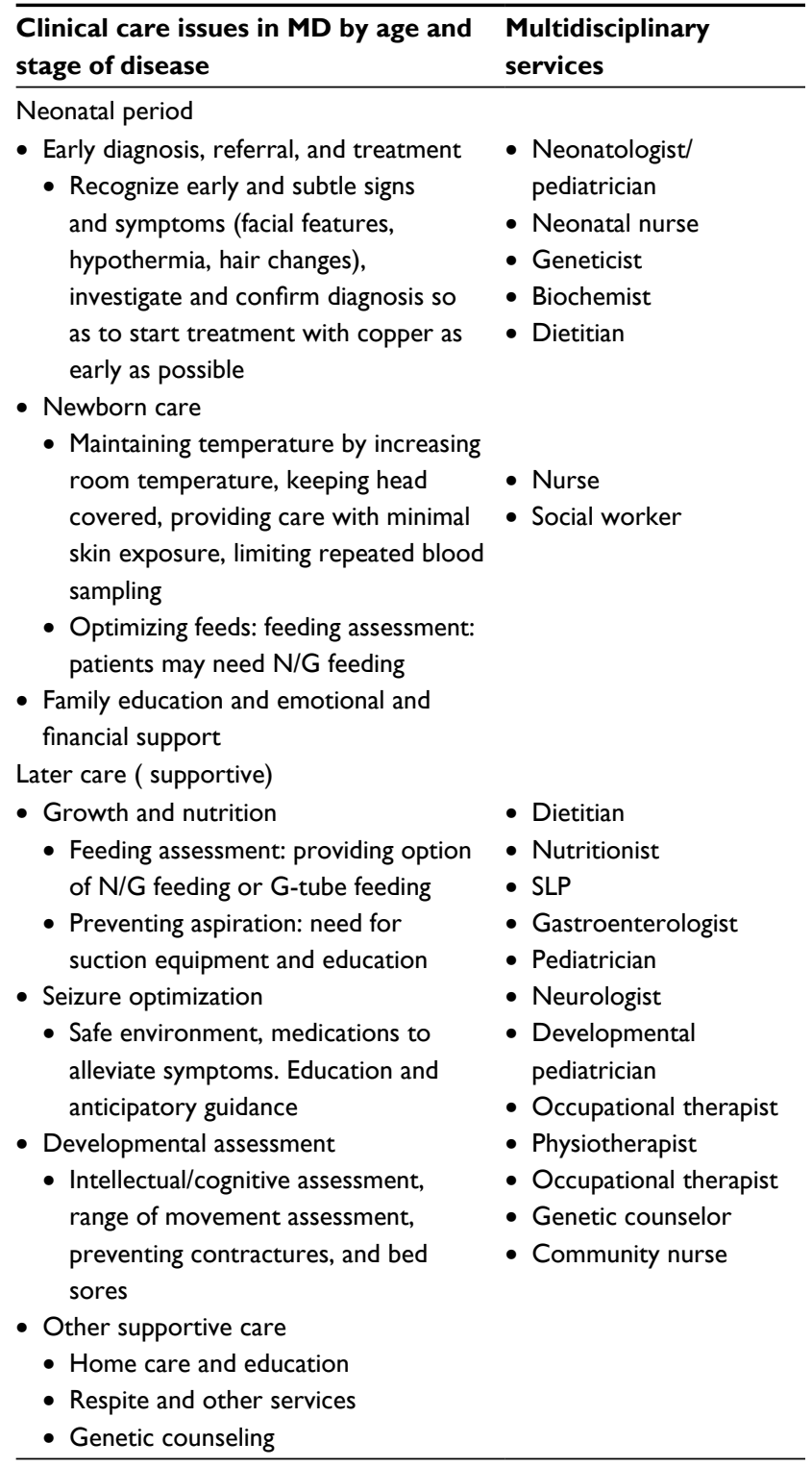

Abbreviations: G-tube, gastric tube; MD, Menkes disease; N/G, nasogastric; SLP, speech and linguistic pathologist.

emotional, financial, and social challenges. A social worker can assist these families by providing counseling services and financial support and also help link families to support groups and the national organization of rare disorders.

\section{Conclusion}

The past several decades have witnessed rapid and tremendous advances in our understanding of MD and related disorders of copper homeostasis. This review highlights the advances and breakthroughs in the basic science and molecular genetics leading to improved recognition and diagnosis. Early diagnosis has been shown to improve survival, and the availability of copper replacement therapy is a step forward. Multidisciplinary research and care teams can not only help in the development 
of clinical trials on MD in the future but also further the goal of improving quality of life for survivors. The work in basic science through the development of animal models holds great promise for future therapies for this otherwise fatal disorder.

\section{Acknowledgments}

The authors would like to thank CA Rupar, $\mathrm{PhD}$, Professor, Departments of Pathology and Laboratory Medicine, Biochemistry, and Pediatrics, for his critical review of the manuscript, comments, and suggestions. There was no funding source for this review.

\section{Disclosure}

Asuri N Prasad has received honoraria from EMD Serono Inc in the last financial year. The authors report no other conflicts of interest in this work.

\section{References}

1. Menkes JH, Alter M, Steigleder GK, Weakely DR, Sung JH. A sex-linked recessive disorder with retardation of growth, peculiar hair, and focal cerebral and cerebellar degeneration. Pediatrics. 1962;29:764-779.

2. O’Brien JS, Sampson EL. Kinky hair disease. II. Biochemical studies. J Neuropathol Exp Neurol. 1966;25(4):523-530.

3. Danks DM, Campbell PE, Stevens BJ, Mayne V, Cartwright E. Menkes's kinky hair syndrome; an inherited defect in copper absorption with widespread effects. Pediatrics. 1972;50(2):188-201.

4. Timer Z, Horn N. Menkes Disease: recent advances and new aspects. J Med Genet. 1997;34(4):265-274.

5. Tumer Z, Moller LB. Menkes Disease. Eur J Hum Genet. 2010;18(5): 511-518.

6. Danks DM, Cartwright E, Stevens BJ, Townley RR. Menkes' kinky hair disease: further definition of the defect in copper transport. Science. 1973;179(78):1140-1142.

7. Tønnesen T, Kleijer WJ, Horn N. Incidence of Menkes disease. Hum Genet. 1991;86(4):408-410.

8. Gu YH, Kodama H, Shiga K, Nakata S, Yanagawa Y, Ozawa H. A survey of Japanese patients with MD from 1990 to 2003: incidence and early signs before typical symptomatic onset, pointing the way to earlier diagnosis. J Inherit Metab Dis. 2005;28(4):473-478.

9. Tsukahara M, Imaizumi K, Kawai S, Kajii T. Occipital horn syndrome: report of a patient and review of the literature. Clin Genet. 1994;45(1):32-35.

10. Horn N, Morton NE, Rao DC. Genetic epidemiology of Menkes disease. Genet Epidemiol. 1986;3(4):225-230.

11. Kapur S, Higgins JV, Delp K, Rogers B. Menkes syndrome in a girl with X-autosome translocation. Am J Med Genet. 1987;26(2):503-510.

12. Sirleto P, Surace C, Santos H, et al. Lyonization effects of the $t(X ; 16)$ translocation on the phenotypic expression in a rare female with MD. Pediatr Res. 2009;65(3):347-351.

13. Desai V, Donsante A, Swoboda KJ, Martensen M, Thompson J, Kaler SG. Favorably skewed X-inactivation accounts for neurological sparing in female carriers of Menkes disease. Clin Genet. 2011;79(2):176-182.

14. Moller LB, Lenartowicz M, Zabot MT, et al. Clinical expression of Menkes disease in females with normal karyotype. Orphanet $J$ Rare Dis. 2012;7:6.

15. Linder MC. The Biochemistry of Copper. New York, NY: Plenum Press; 1991:73-134

16. Linder MC, Wooten L, Cerveza P, Cotton S, Shulze R, Lomeli N. Copper transport. Am J Clin Nutr. 1998;67(5 suppl):S965-S971.
17. Vuori E, Kuttunen P. The concentrations of copper and zinc in human milk. A longitudinal study. Acta Paediatr Scand. 1979;68(1):33-37.

18. Wapnir RA. Copper absorption and bioavailability. Am J Clin Nutr. 1998;67(5 Suppl):1054-1060.

19. Turnlund JR, Keyes WR, Anderson HL, Acord LL. Copper absorption and retention in young men at three levels of dietary copper using the stable isotope, 65Cu. Am J Clin Nutr. 1989;49(5):870-878.

20. Scott KC, Turnlund JR. Compartment model of copper metabolism in adult men. J Nutr Biochem. 1994;5(7):342-350.

21. Horn N, Tumer Z. Menkes disease and the occipital horn syndrome. In: Royce PM, Steinmann B, editors. Connective Tissue and its Heritable Disorders: Molecular, Genetic, and Medical Aspects. New York, NY: John Wiley and Sons Inc; 2002:651-685.

22. Lee J, Penna MM, Nose Y, Thiele DJ. Biochemical characterization of the human copper transporter Ctr1. J Biol Chem. 2002;277(6): $4380-4387$.

23. Formigari A, Irato P, Santon A. Zinc, antioxidant systems and metallothionein in metal mediated-apoptosis: biochemical and cytochemical aspects. Comp Biochem Physiol C Toxicol Pharmacol. 2007;146(4): 443-459.

24. Speisky H, Gómez M, Burgos-Bravo F, et al. Generation of superoxide radicals by copper-glutathione complexes: redox-consequences associated with their interaction with reduced glutathione. Bioorg Med Chem. 2009;17(5):1803-1810.

25. Hamza I, Prohaska J, Gitlin JD. Essential role for Atox 1 in the coppermediated intracellular trafficking of the Menkes ATPase. Proc Natl Acad Sci USA. 2003;100(3):1215-1220.

26. Turski ML, Thiele DJ. New roles for copper metabolism in cell proliferation, signaling, and disease. J Biol Chem. 2009;284(2):717-721.

27. Culotta VC, Yang M, O'Halloran TV.Activation of superoxide dismutases: putting the metal to the pedal. Biochim Biophys Acta. 2006;1763(7): $747-758$.

28. Camakaris J, Petris MJ, Bailey L, et al. Gene amplification of the Menkes (MNK; ATP7A) P-type ATPase gene of CHO cells is associated with copper resistance and enhanced copper efflux. Hum Mol Genet. 1995;4(11):2117-2123.

29. Monty JF, Llanos RM, Mercer JF, Kramer DR. Copper exposure induces trafficking of the Menkes protein in intestinal epithelium of ATP7A transgenic mice. J Nutr. 2005;135(12):2762-2766.

30. Jankov RP, Boerkoel CF, Helimann J, et al. Lethal neonatal Menkes' disease with severe vasculopathy and fractures. Acta Paediatr. 1998;87(12):1297-1300.

31. El Meskini R, Crabtree KL, Cline LB, Mains RE, Eipper BA, Ronnett GV. ATP7A (Menkes protein) functions in axonal targeting and synaptogenesis. Mol Cell Neurosci. 2007;34(3):409-421.

32. Schlief ML, West T, Craig AM, Holtzman DM, Gitlin JD. Role of the Menkes copper- transporting ATPase in NMDA receptor-mediated neuronal toxicity. Proc Natl Acad Sci U SA. 2006;103(40):14919-14924.

33. Kaler SG, Goldstein DS, Holmes C, Salerno JA, Gahl WA. Plasma and cerebrospinal fluid neurochemical pattern in Menkes disease. Ann Neurol. 1993;33(2):171-175.

34. Kennerson ML, Nicholson GA, Kaler SG, et al. Missense mutations in the copper transporter gene ATP7A cause X-linked distal hereditary motor neuropathy. Am J Hum Genet. 2010;86(3):343-352.

35. Qin Z, Gongora MC, Ozumi K, et al. Role of Menkes ATPase in angiotensin II-induced hypertension a key modulator for extracellular superoxide dismutase function. Hypertension. 2008;52(5):945-951.

36. Rabik CA, Maryon EB, Kasza K, Shafer JT, Bartnik CM, Dolan ME. Role of copper transporters in resistance to platinating agents. Cancer Chemother Pharmacol. 2009;64(1):133-142.

37. White C, Lee J, Kambe T, Fritsche K, Petris MJ. A role for the ATP7A copper transporting ATPase in macrophage bactericidal activity. $J$ Biol Chem. 2009;284(49):33949-33956.

38. Kim BE, Turski ML, Nose Y, Casad M, Rockman HA, Thiele DJ. Cardiac copper deficiency activates a systemic signaling mechanism that communicates with the copper acquisition and storage organs. Cell Metab. 2010;11(5):353-363. 
39. Horn N. Copper incorporation studies on cultured cells for prenatal diagnosis of Menkes' disease. Lancet. 1976;307(7970):1156-1158.

40. Verga V, Hall BK, Wang SR, Johnson S, Higgins JV, Glover TW. Localization of the translocation breakpoint in a female with Menkes syndrome to Xq13.2-q13.3 proximal to PGK-1. Am J Hum Genet. 1991;48(6):1133-1138.

41. Tumer Z, Tommerup N, Tonnesen T, Kreuder J, Craig IW, Horn N. Mapping of the Menkes locus to Xq13.3 distal to the X-inactivation center by an intrachromosomal insertion of the segment Xq13.3-q21.2. Hum Genet. 1992;88(6):668-672.

42. Chelly J, Tumer Z, Tonnesen T, et al. Isolation of a candidate gene for Menkes disease that encodes a potential heavy metal binding protein. Nat Genet. 1993;3(1):14-19.

43. Mercer JA, Livingston J, Hall B, et al. Isolation of a partial candidate gene for Menkes disease by positional cloning. Nat Genet. 1993; 3(1):20-25.

44. Vulpe C, Levinson B, Whitney S, Packman S, Gitschier J. Isolation of a candidate gene for Menkes disease and evidence that it encodes a copper-transporting ATPase. Nat Genet. 1993;3(1):7-13.

45. Stenson PD, Mort M, Ball EV, et al. The human gene mutation database: 2008 update. Genome Med. 2009;1(1):13.

46. Gu YH, Kodama H, Murata Y, et al. ATP7A gene mutations in 16 patients with Menkes disease and a patient with occipital horn syndrome. Am J Med Genet. 2001;99(3):217-222.

47. Kaler SG, Liew CJ, Donsante A, Hicks JD, Sato S, Greenfield JC. Molecular correlates of epilepsy in early diagnosed and treated Menkes disease. J Inherit Metab Dis. 2010;33(5):583-589.

48. Tumer Z, Moller LB, Horn N. Screening of 383 unrelated patients affected with Menkes disease and finding of 57 gross deletions in ATP7A. Hum Mutat. 2003;22(6):457-464.

49. Kaler SG. Inborn errors of copper metabolism. Handb Clin Neurol. 2013;113:1745-1754.

50. Tumer Z. An overview and update of ATP7A mutations leading to Menkes disease and occipital horn syndrome. Hum Mutat. 2013;34(3): 417-429.

51. Kaler SG. Metabolic and molecular bases of Menkes disease and occipital horn syndrome. Pediatr Dev Pathol. 1998;1(1):85-98.

52. Dagenais SL, Adam AN, Innis JW, Glover TW. A novel frameshift mutation in exon 23 of ATP7A (MNK) results in occipital horn syndrome and not in Menkes disease. Am J Hum Genet. 2001;69(2):420-427.

53. Moizard MP, Ronce N, Blesson S, et al. Twenty-five novel mutations including duplications in the ATP7A gene. Clin Genet. 2011;79(3): 243-253.

54. Kaler SG. ATP7A-related copper transport diseases-emerging concepts and future trends. Nat Rev Neurol. 2011;7(1):15-29.

55. Kodoma H, Murata Y, Kobayashi M. Clinical manifestations and treatment of Menkes disease and its variants. Pediatr Int. 1999;41(4):423-429.

56. Grange DK, Kaler SG, Albers GM, Petterchak JA, Thorpe CM, DeMello DE. Severe bilateral panlobular emphysema and pulmonary arterial hypoplasia: unusual manifestations of Menkes disease. $\mathrm{Am} \mathrm{J}$ Med Genet A. 2005;139(2):151-155.

57. Gu YH, Kodama H, Kato T. Congenital abnormalities in Japanese patients with Menkes disease. Brain Dev. 2012;34(9):746-749.

58. Moore CM, Howell RR. Ectodermal manifestations in Menkes disease. Clin Genet. 1985;28(6):532-540.

59. Mizuguchi M, Itoh M, Ozawa H, Morikawa Y. A 2-year-old boy with hypoactivity of neonatal onset and profound developmental delay. Neuropathology. 2007;27(2):145-149.

60. Daish P, Wheeler EM, Roberts PF, Jones RD. Menkes syndrome: report of a patient treated from 21 days of age with parenteral copper. Arch Dis Child. 1978;53(12):956-958.

61. Sasaki G, Ishii T, Sato S, et al. Multiple polypoid masses in the gastrointestinal tract in patient with Menkes disease on copper- histidinate therapy. Eur J Pediatr. 2004;163(12):745-746.

62. Okada T, Sasaki F, Honda S, Miyagi H, Kubota M, Todo S. Menkes disease with gastroesophageal reflux disease and successful surgical treatment: a case report and literature. TurkJ Pediatr. 2010;52(3):333-335.
63. Shiihara T, Kato M, Honma T, et al. Progressive sliding hiatal hernia as a complication of Menkes' syndrome. J Child Neurol. 2002;17(5):401-402.

64. Sartoris DJ, Luzzatti L, Weaver DD, Macfarlane JD, Hollister DW, Parker BR. Type IX Ehlers-Danlos syndrome. A new variant with pathognomonic radiographic features. Radiology. 1984;152(3):665-670.

65. Kaler SG, Westman JA, Bernes SM, et al. Gastrointestinal hemorrhage associated with gastric polyps in Menkes disease. J Pediatr. 1993;122(1):93-95.

66. Jeong GU, Cho A, Hwang H, et al. A case of Menkes disease with unusual hepatomegaly. Korean J Pediatr. 2008;51(5):538-541.

67. Royce PM, Steinmann B. Markedly reduced activity of lysyl oxidase in skin and aorta from a patient with Menkes disease showing unusually severe connective tissue manifestations. Pediatr Res. 1990;28(2): 137-141.

68. Royce PM, Camakaris J, Danks DM. Reduced lysyl oxidase activity in skin fibroblast from patients with Menkes syndrome. Biochem J. 1980;192(2):579-586.

69. Menkes JH. Kinky hair disease: twenty five years later. Brain Dev. 1988;10(2):77-79.

70. Menkes JH. Kinky hair disease. Pediatrics. 1972;50(2):181-183.

71. Grover WD, Johnson WC, Henkin RI. Clinical and biochemical aspects of trichopoliodystrophy. Ann Neurol. 1979;5(1):65-71.

72. Smith VV, Anderson G, Malone M, Sebire NJ. Light microscopic examination of scalp hair samples as an aid in the diagnosis of pediatric disorders: retrospective review of more than 300 cases from a single centre. J Clin Pathol. 2005;58(12):1294-1298.

73. Whiting DA. Structural abnormalities of the hair shaft. J Am Acad Dermatol. 1987;16(1 pt 1):1-25.

74. Kaler SG. Diagnosis and therapy of Menkes syndrome, a genetic form of copper deficiency. Am J Clin Nutr. 1998;67(suppl 5):S1029-S1034.

75. Kaler SG, Holmes CS, Goldstein DS. Dopamine beta-hydroxylase deficiency associated with mutations in a copper transporter gene. Adv Pharmacol. 1998;42:66-68.

76. Robain O, Aubourg P, Routon MC, Dulac O, Ponsot G. Menkes disease: a Golgi and electron microscopic study of the cerebellar cortex. Clin Neuropathol. 1988;7(2):47-52.

77. Bindu PS, Taly AB, Kothari S, et al. Electro-clinical features and magnetic resonance imaging correlates in Menkes disease. Brain Dev. 2013;35(5):398-405.

78. Bahi-Buisson N, Kaminska A, Nabbout R, et al. Epilepsy in Menkes disease: analysis of clinical stages. Epilepsia. 2006;47(2):380-386.

79. Jayawant S, Halpin S, Wallace SG. Menkes kinky hair disease: an unusual case. Eur J Pediatr Neurol. 2000;4(3):131-134.

80. Friedman ET, Harden A, Koivikko M, Pampiglione G. Menkes'disease: neurophysiological aspects. J Neurol Neurosurg Psychiatry. 1978;41(6):505-510.

81. White SR, Reese K, Sato S, Kaler SG. Spectrum of EEG findings in Menkes disease. Electroencephalogr Clin Neurophysiol. 1993;87(1): 57-61.

82. Kaler SG, Holmes CS, Goldstein DS, et al. Neonatal diagnosis and treatment of Menkes disease. N Engl J Med. 2008;358(6):605-614.

83. Barnard RO, Best PV, Erdohazi M. Neuropathology of Menkes' disease. Dev Med Child Neurol. 1978;20(5):586-597.

84. Okeda R, Gei S, Chen I, Okaniwa M, Shinomiya M, Matsubara O. Menkes' kinky hair disease: morphological and immunohistochemical comparison of two autopsied patients. Acta Neuropathol. 1991;81(4):450-457.

85. Proud VK, Mussell HG, Kaler SG, Young DW, Percy AK. Distinctive Menkes disease variant with occipital horns: delineation of natural history and clinical phenotype. Am J Med Genet. 1996;65(1):44-51.

86. Herman TE, McAlister WH, Boniface A, Whyte MP. Occipital horn syndrome. Pediatr Radiol. 1992;22(5):363-365.

87. Danks DM. The mild form of Menkes disease: progress report on the original case. Am J Med Genet. 1988;30(3):859-864.

88. Gerdes AM, Tønnesen T, Pergament E, et al. Variability in clinical expression of Menkes syndrome. Eur J Pediatr. 1988;142(2):132-135.

89. Westman JA, Richardson DC, Rennert OM, Morrow G 3rd. Atypical Menkes steely hair disease. Am J Med Genet. 1998;30(3):853-858. 
90. Møller LB, Mogensen M, Horn N. Molecular diagnosis of Menkes disease: genotype-phenotype correlation. Biochimie. 2009;91(10):1273-1277.

91. Tümer Z, Lund C, Tolshave J, Vural B, Tønnesen T, Horn N. Identification of point mutations in 41 unrelated patients affected with Menkes disease. Am J Hum Genet. 1997;60(1):63-71.

92. Das S, Levinson B, Whitney S, Vulpe C, Packman S, Gitschier J. Diverse mutations in patients with Menkes disease often lead to exon skipping. Am J Hum Genet. 1994;55(5):883-889.

93. Kaler SG, Gahl WA, Berry SA, Holmes CS, Goldstein DS. Predictive value of plasma catecholamine levels in neonatal detection of Menkes disease. J Inherit Metab Dis. 1993;16(5):907-908.

94. Kaler SG, Tumer Z. Prenatal diagnosis of Menkes disease. Prenat Diagn. 1998;18(3):287-289.

95. Tønnesen T, Gerdes AM, Damsgaard E, et al. First-trimester diagnosis of Menkes disease: intermediate copper values in chorionic villi from three affected male fetuses. Prenat Diagn. 1989;9(3):159-165.

96. Vonk WI, Wijmenga C, van de Sluis B. Relevance of animal models for understanding mammalian copper homeostasis. Am J Clin Nutr. 2008;88(suppl 3):S840-S845.

97. Lenartowicz M, Krzeptowski W, Lipinski P, et al. Mottled mice and non-mammalian models of Menkes disease. Front Mol Neurosci. 2015;8:72.

98. Fraser AS, Nay T. Growth of the mouse coat. II. Effect of sex and pregnancy. Aust J Biol Sci. 1953;6(4):645-656.

99. Hunt DM. Primary defect in copper transport underlies mottled mutants in the mouse. Nature. 1974;249(460):852-854.

100. Tanaka K, Kobayashi K, Fujita Y, Fukuhara C, Onosaka S, Min K. Effects of chelators on copper therapy of macular mouse, a model animal of Menkes' kinky disease. Res Commun Chem Pathol Pharmacol. 1990;69(2):217-227.

101. Kodama H, Sato E, Gu YH, Shiga K, Fujisawa C, Kozuma T. Effect of copper and diethyldithiocarbamate combination therapy on the macular mouse, an animal model of Menkes disease. J Inherit Metab Dis. 2005;28(6):971-978.

102. Lenartowicz M, Krzeptowski W, Koteja P, Chrzascik K, Moller LB. Prenatal treatment of mosaic mice (Atp7a mo-ms) mouse model for Menkes disease, with copper combined by dimethyldithiocarbamate (DMDTC). PLoS One. 2012;7(7):e40400.

103. Mendelsohn BA, Yin C, Johnson SL, Wilm TP, Solnica-Krezel L, Gitlin JD. Atp7a determines a hierarchy of copper metabolism essential for notochord development. Cell Metab. 2006;4(2):155-162.

104. Madsen EC, Morcos PA, Mendelsohn BA, Gitlin JD. In vivo correction of a Menkes disease model using antisense oligonucleotides. Proc Natl Acad Sci U S A. 2008;105(10):3909-3914.
105. Norgate M, Lee E, Southon A, et al. Essential roles in development and pigmentation for the Drosophila copper transporter DmATP7. Mol Biol Cell. 2006;17(1):475-484.

106. Bahadorani S, Bahadorani P, Marcon E, Walker DW, Hilliker AJ. A Drosophila model of Menkes disease reveals a role for DmATP7 in copper absorption and neurodevelopment. Dis Model Mech. 2010;3(1-2): 84-91.

107. Staphanede A, Giorgi M, Attilakos A, Papadopoulos J, Tsirouda M, Dinopoulos A. Late onset treatment on Menkes disease with a novel single nucleotide deletion in the ATP7A gene. Eur J Pediatr Neurol. 2015;19:S121.

108. Tchan MC, Wilchen B, Christodoulou J. The mild form of Menkes disease: a 34 year progress report on the original case. JIMD Rep. 2013;9:81-84.

109. Sander C, Niederhoff H, Horn N. Life-span and Menkes kinky hair syndrome: report of a 13- year course of this disease. Clin Genet. 1988;33(3):228-233.

110. Kaler SG, Das S, Levinson B, et al. Successful early copper therapy in Menkes disease associated with a mutant transcript containing a small in-frame deletion. Biochem Mol Med. 1996;57(1):37-46.

111. Christodoulou J, Danks DM, Sarkar B, et al. Early treatment of MD with parenteral copper -histidine: long-term follow-up of four treated patients. Am J Med Genet. 1998;76(2):154-164.

112. Kaler SG. Neurodevelopment and brain growth in classic MD is influenced by age and symptomatology at initiation of copper treatment. J Trace Elem Med Biol. 2014;28(4):427-430.

113. Prasad AN, Levin S, Rupar CA, Prasad C. Menkes disease and infantile epilepsy. Brain Dev. 2011;33(10):866-876.

114. Tang J, Donsante A, Desai V, Patronas N, Kaler SG. Clinical outcomes in Menkes disease patients with a copper-responsive ATP7A mutation, G727R. Mol Genet Metab. 2008;95(3):174-181.

115. Sherwood G, Sarkar B, Kortsak AS. Copper histidinate therapy in Menkes' disease: prevention of progressive neurodegeneration. J Inherit Metab Dis. 1989;12(2):393-396.

116. Kaler SG. Menkes disease mutations and response to early copper histidine treatment. Nat Genet. 1996;13(1):21-22.

117. Nassogne M-C, Sharrad M, Hertz-Pannier L, et al. Massive subdural haematomas in Menkes disease mimicking shaken baby syndrome. Childs Nerv Syst. 2002;18(12):729-731.

118. Jain P, Sharma S, Sankhyan N, et al. Macrocephaly with diffuse white matter changes simulating a leukodystrophy in Menkes disease. Indian J Pediatr. 2013;80(2):160-162.

119. Saha S, Mridha D. An unusual cause for focal convulsions: Menkes kinky hair disease. J Pediatr Neurol. 2013;11(02):123-125.
Journal of Multidisciplinary Healthcare

\section{Publish your work in this journal}

The Journal of Multidisciplinary Healthcare is an international, peerreviewed open-access journal that aims to represent and publish research in healthcare areas delivered by practitioners of different disciplines. This includes studies and reviews conducted by multidisciplinary teams as well as research which evaluates the results or conduct of such teams or health-
Dovepress

care processes in general. The journal covers a very wide range of areas and welcomes submissions from practitioners at all levels, from all over the world The manuscript management system is completely online and includes a very quick and fair peer-review system. Visit http://www.dovepress.com/ testimonials.php to read real quotes from published authors. 